Volume 7 Issue 1, March 2020

Nationally Accredited Journal,

Decree No. B/4130/E5/E5.2.1/2019

\title{
Act Making Mechanisms Sale And Purchase Agreement (SPA) Public By Authentic As Evidence In The Process Of Transition Of Land
}

\begin{abstract}
Gigih Bella Wicaksono Kenedy ${ }^{1}$ and Lathifah Hanim²
Abstract. SPA is a preliminary agreement on the sale and purchase agreement whose existence is recognized by Law No 1 of 2011 on Housing and Settlement (as lex), an agreement of this kind can be allocated to the object of the agreement in the form of fixed objects. The journal aims to determine: 1) Mechanism Creation Act Sale and Purchase Agreement (SPA) by the Public in the process of transfer of rights on the ground. 2) As a result of the Law of Sale and Purchase Agreement (SPA) as an Agreement.

The method of this journal Sociological Juridical approach. Data were collected from literature research and field research. Data collection tool is the study of literature and interviews. Data was analyzed using qualitative approach by using inductive-deductive logic thinking.

The results showed that: 1) Making mechanism Sale and Purchase Agreement (SPA) by the Public in the transition process of land rights by submitting the data themselves form: ID, KK, Certificate etc. From the data obtained all the documents submitted Copied accordance with the original, which will be attached to the Minutes of Deed Sale and Purchase Agreement (SPA) 2) The legal consequences of the Sale and Purchase Agreement (SPA) as a preliminary agreement (voor overeenkomst) is binding on the party who made it, where the parties both sellers and prospective buyers agreed to purchase land and buildings.

Keywords: Transition on Land; Sale; SPA.
\end{abstract}

\section{Introduction}

Indonesia is a developing country, with the development of society and the need to develop the land and therefore society requires sufficient land area. It is directly proportional to the increasing density of population requiring treatment with careful planning with the participation of the funds and resources available within the community. ${ }^{3}$

The function of the soil is an important part of human life, in addition to matching the planting, the soil is also a key requirement for a development in the country. Land can also be used to build a home or a place to stay for the community itself, because one of the primary needs of man is to have a home that is certainly built on a plot of land. According to the views of people with a home, a person deemed to be financially stable so no wonder if everyone will do all it can acquire houses and land. ${ }^{4}$

\footnotetext{
${ }^{1}$ Student Master of Notary Program, Faculty of Law, Sultan Agung Islamic University email wgigih728@gmail.com

${ }^{2}$ Faculty of Law, University Islam Sultan Agung Semarang

${ }^{3}$ C. Djemabut Blaang, 1986, Perumahan dan Pemukiman sebagai Kebutuhan Pokok, Obor Jakarta, Indonesia, p. 4

${ }^{4}$ Jimmy sembiring Joses, 2010, Panduan Mengurus Sertifikat Tanah, Visimedia, Jakarta, p.1
} 
Along with the growing population, the need for land continues to rise, to meet the demand for land is sometimes led to disputes or conflicts within the community, to regulate the use of land in order not to cause discord or conflict then on 24 September 1960 the government issued Law No , 5 of 1960 on Basic Regulation of Agrarian (BAL). The purpose of the issuance of BAL to provide legal certainty on the land, because prior to the issuance of the BAL, Indonesia happened two legal systems concerning land purchase is the purchase of land based on customary law and purchase of land by Western law contained in the draft Civil Code.

Under customary law, the purchase is a legal act in the form of land concerned by the seller to the buyer for all time at which the buyer handed over the price with the seller, the price payment and delivery rights to be done at the same time even though only part of the payment, according to the law custom is considered paid in full, buying and selling in the law made by cash.

According to civil law, land transfer is deemed to have occurred with the consensus reached between the seller and the buyer, even in the form of certificates of land rights have not been submitted and agreed price has not been paid in full. Buying and selling properties konsensuil as provisions in Article 1458 of the Civil Code. Land rights sold it recently moved to the buyer to do other legal act called "handing juridical" as found in Article 1459 of the Civil Code. ${ }^{5}$

BAL does not define clearly about buying and selling, but it can be concluded that the purchase is a legal act by transferring the ownership (of land forever) by the seller to the buyer at the time also gave the price to the seller. Which resulted in the shift of the sale and purchase of land rights from the seller to the purchaser including agrarian law.

At this time it is not easy to gain ground, especially in urban areas. One way to acquire land is through buying and selling, which in fact is the transfer of land title from the seller to the buyer, so with the sale and purchase between the parties is automatically land ownership rights have been transferred to the buyer. The ownership of land is a land certificate as valid proof of ownership.

Buying and selling land is usually done by having an agreement to provide legal certainty ${ }^{6}$, But at the time of the former Dutch colonial rule are still many people who do the buying and selling land only with receipt (girik, lots) only. Proof of ownership of the land by using the receipts have not got legal certainty.

Registration of land rights is important to provide legal certainty and protection to the right to a plot of land and other rights registered in order to easily be able to prove himself as the holder of the right in question is evidenced by the certificate of land, it is the purpose of registration land under Article 3 of Government Regulation No. 24 of 1997 on Land Registration.

The purpose of this is what is the main purpose of the land registry as covered by Article 19 of the BAL (Basic Agrarian Law). The authority of land titling and land registration activities are regulated by the BPN No.2 of 2013 on the Land Rights that

\footnotetext{
${ }^{5}$ Harun Al Rashid, 1987, Sekilas Tentang Jual Beli Tanah, Ghalia Jakarta, Indonesia, p.52

6 HMT Sahat Sinaga, 2007, Jual Beli Tanah dan Pencatatan Peralihan Hak, Sutra Library, Bandung, p.1
} 
would regulate all the requirements for the registration of land to facilitate civil society that only trades with a receipt. The process of buying and selling a piece of receipt is not prohibited or illegal, but in a way that can make it difficult for buyers when will register rights to land bought.

Article 7 of the Government Regulation No. 24 of 1997 specifies that the Land Deed, hereinafter the Public, is set in a Regulation. The provisions of Article 7 of Government Regulation No. 24 of 1997 was followed by the issuance of Government Regulation No. 37 of 1998 on the Regulation of Officials of Land (Official Gazette of the Republic of Indonesia load of 1998 No. 52, State Gazette of the Republic of Indonesia Number 3746) as amended by the Indonesian Government Regulation No. 24 of 2016 on the amendment of Government Regulation No. 37 of 1998 on the Regulation of the Department of Land Deed (official Gazette of the Republic of Indonesia of 2016 Number 120, Supplement to State Gazette of the Republic of Indonesia Number 5893), hereinafter referred to as the Department of Public Regulation.

PPAT perform basic tasks for most activities by creating a land registry as proof of the deed he had done certain legal actions regarding the rights or proprietary right of the Housing Unit. Legal acts referred to are: purchase, exchange, donation, inclusion in the company (inbreng), with the distribution of rights, giving the Right to Use of Land Ownership, of Encumbrance, and Authorization of Mortgage.

In the practice of buying and selling land rights to the object preceded by an agreement referred to the Sale and Purchase Agreement or which in practical terms is called SPA, R. Subekti said, that the sale and purchase agreement is an agreement between the seller and the buyer before the sale and purchase due to the elements that must be met for the transaction, such as a certificate of land rights yet because it is still in the process of, or have not occurred amortization rates or taxes imposed on the sale and purchase of land rights can not be paid either by the seller or buyers. ${ }^{7}$

In order to clarify that the existing problems will be discussed more focused and consistent with the objectives and the expected goals, it is important to formulate the issues to be discussed. The formulation of the problem to be addressed in this study is how the mechanism of creation of the Sale and Purchase Agreement (SPA) by the Public in the transition process of land rights and what the consequences of Law Sale and Purchase Agreement (SPA) as an Agreement.

\section{Research methods}

The approach used in this study is discuss juridical empirical method. Juridical empirical legal research is a method that attempts to view the law in terms of the real or alleged to view, examine how the work of law in society ${ }^{8}$,

In this case judicial approach used to analyze various regulations concerning Making the Sale and Purchase Agreement (SPA), whereas the empirical approach used to

\footnotetext{
${ }^{7}$ R. Subekti, 1998, Aspek-Aspek Hukum Perikatan Nasional, Citra Aditya Bakti, Bandung, p. 29

8 Cholid Narbuko and H. Abu Achmadi, 2002, Metodologi Penelitian, Jakarta: PT.Bumi Character, p 14
} 
analyze the legal views of the behavior of people in public life, always interact and relate to aspects of society. ${ }^{9}$

Specifications of this study is descriptive analysis a study that attempted to describe the legal issues, the legal system and examine or analyze them according to the needs of the research in question. To obtain information and data that is accurate, relevant and related to the problem and the solution writing this journal, the authors conducted research in the Office of Notary / PPAT, and the subjects in this study is the notary and the parties involved in the transaction.

\section{Results and Discussion}

\subsection{Mechanism Creation Act Sale and Purchase Agreement (SPA) by the Public in the Transition Process of Land Rights}

In practice the procedures of sale and purchase agreement as well as the creation of an authentic deed (deed Partij), such as: agreement, power of attorney, and others. The procedure in the manufacture and purchase agreement, among others:

- Submit the identities of the parties to the notary, as well as

- Identity Card (ID)

- Family Card (KK)

- Marriage Certificate (for married)

- Divorce Certificate (for those who are divorced)

- Certificate of Heirs (for representing the heirs)

- Submit supporting evidence, as

- Death Certificate (for those who showed the dead)

- letter Authorization / Approval (for that represent or powered)

- Proof of Identity / Ownership Rights (certificate / book of land (Right / Broking / Right to Housing Unit and others.

- receipt of payment

- Other Statement

From the data obtained all the documents submitted Copied accordance with the original, which will be attached to the Minutes of Deed Sale and Purchase Agreement (SPA), all documents both identity and supporting evidence must be examined on the subject of the validity period, the truth of its contents and authenticity of the documents.

Especially with regard to the evidence Landmarks / Ownership Rights (certificate / book of land (Right / Broking / Rights Unit Housing Project, etc.) must be checked into the National Land Agency (BPN) / local Land Office at the place where the object is located, the the adjusted and matched whether the contents contained in the certificate is in accordance with that contained in the Land Book in the local Land Office. this check is performed in order to avoid abuse of false documents as well as falsification of certificates in the sale and purchase transaction and purchase

9 Bambang Sunggono, 2003, Metodologi Penelitian Hukum, Jakarta: PT.Raja GRAFINDO PERSADA, p.43 
will be.

The accuracy and precision of the key prudence in the conduct of his office. When the result of checking the certificate at the Land Office is clean / clear, then making a sale and purchase can be done in presence of which the notary create and read out the contents of the deed of the purchase agreement. At the time of the deed of sale and purchase agreement is signed should be a clause about the Power to exercise the powers of the First Party Second Party to sell these objects when all the rights and obligations of the parties have been met. Receipt of payment of the sums done by the gradual payment / installment must be accompanied by a receipt as proof of payment has been given a sum of money as agreed.

Execution of Sale and Purchase Agreement (SPA) began at the time of Party B Party $C$ invited to meet with the notary $Z$ in Bandung, which is known by the $C$ and convey meaning. Later on the same date the $C$ prompt to notary $Z$ to create a Sale and Purchase Agreement (SPA) and the Power of Attorney to Sell from Party A to Party $C$ made by the notary, which basically said the transition of land rights has been paid off, when in fact recently paid a portion of the stamp to be given to a, then the next day make notary $Z$ Sale and Purchase Agreement which is requested by the host B and host notary $Z$ create $C$. Sale and Purchase Agreement with inappropriate procedures should.

In terms of the deed, deed of Sale and Purchase Agreement signed separately between the seller, buyer, Notary, and witnesses. Act signed by the parties is in the form of draft minutes were not yet given a date and a number of acts, file draft minutes shall be signed in advance by the Buyer in the Notary Office Z Bandung, then taken by Mr B to the seller of this Mrs. A and Mr. D (ex-husband) to be signed, after it was handed over by Mr B to the notary $Z$, and the end date of the deed and the deed required and subsequently signed by the witness and notary $Z$, then the Sale and Purchase Agreement was already full booked and already signed by witness -saksi and notary and a copy submitted to the parties.

Based on the above it can be stated that the signing of the entire Purchase Agreement Act has never been done in presence of $Z$ in the city of Bandung, this is evidenced by the parties never met the seller and the buyer in presence of the $Z$

\subsection{Effects of Sale and Purchase Agreement (SPA) as an Agreement Introduction}

The legal consequences are the result of an action taken to obtain a result desired by the perpetrator and is recognized by law. Their actions are legal actions are actions taken to achieve a result that is required by law. Therefore, the legal effect is all the consequences arising from all legal actions undertaken by law subject to the legal objects or other consequences caused by certain events by the law in question has been determined or considered as legal consequences. ${ }^{10}$

${ }^{10}$ Saleh, 2004, Pengantar IImu Hukum, Jakarta: Sinar Grafika, p. 295 
As a result of the law is the source of the birth of the rights and obligations of legal subjects concerned. Like, the Sale and Purchase Agreement have been born a legal effect of the purchase agreement is subject to the law have the right to obtain goods and have the obligation to pay the freight. Vice versa, other legal subjects have the right to earn money, but it also has an obligation to deliver the goods.

It is clear that the subject of legal actions undertaken against the object of the law creates legal effect. Arising from legal consequences when someone is buying and selling, it gives birth to the legal relationship between the two. Similarly, the sale and purchase agreement, which is a preliminary agreement that is konsensuil, but have created rights and obligations between the parties that made it. As a result of the shift of the SPA is not the right kind of seller to the buyer, but the occurrence of an agreement between the seller (developer) and potential buyers to make the act of buying and selling, where an agreement in the SPA will be set forth in an agreement AJB tree.

Basically, the sale and purchase agreement (agreement to sell) different sales and purchase agreement (sale agreement). SPA is the buying and selling of objects in which the parties agree that ownership of the property will be transferred to the buyer at a future time. While the agreement is the purchase of the property on which the object is immediately transferred to the buyer. ${ }^{11}$

Sale and purchase agreement or contract of sale in the UK are distinguished in the sale or agreement to sell. The difference can be seen in Article 1, paragraph 3 of the Sale of Goods Act, $1893 .{ }^{122}$ When a contract of sale alienation occurs immediately, then called the sale agreement; but when the transfer of ownership is separate from the time of the agreement or hung on a condition or a specific condition in a future, then called the agreement to sell the lease agreement. ${ }^{12}$

A sale is a sale and purchase agreement as well as the transfer of ownership or conveyance (introductory) that is similar to buying and selling by Customary Law that is real and present, while an agreement to sell is nothing more than an opovereenkomst normal according to the Book of the Law Legal obligatoir civil nature.

Under the provisions of Law No 1 of 2011 on Housing and Settlement, buying and selling homes in the housing market is still under construction with preliminary agreement of sale and purchase. The preliminary sale and purchase agreement shall be regulated further in Decree of the Minister of Housing No 9 of 1995 on the Sale and Purchase Guidelines. Therefore, Law No. 1 of 2011 on Housing and Settlement and Housing Minister Decree No. 9 of 1995, as lex which is the basis governing the Sale and Purchase Agreement. Sale and Purchase Agreement either negotiation or agreement between the developer and the prospective buyer about the object of sale. Based Kemenpera No 9 of 1995 that the need for the SPA to be made by the seller (developer) and the potential buyers to secure the interests of sellers and buyers and minimize disputes that arise in the future, before the signing of the deed of sale by Land Deed. Once agreement has been reached between the parties, then the next agreement on sale and purchase will be poured into a sale and purchase agreement

\footnotetext{
${ }^{11}$ Abdul Kadir Muhammad, 1980, Hukum Perjanjian, Singapore: Alumni, p. 243

${ }^{12}$ R. Subekti, 1976, Aspek-Aspek Hukum Perikatan Nasional, Singapore: Alumni, p. 21
} 
Volume 7 Issue 1, March 2020

Nationally Accredited Journal,

Decree No. B/4130/E5/E5.2.1/2019

(the principal agreement).

\section{Closing}

\subsection{Conclusion}

Based on what has been described in the previous section, it can be concluded as follows:

- Making mechanism Sale and Purchase Agreement (SPA) by the Public in the transition process of land rights by submitting the data themselves form: ID, KK, Certificate etc. From the data obtained all the documents submitted Copied accordance with the original, which will be attached to the Minutes of Deed Sale and Purchase Agreement (SPA), all documents both identity and supporting evidence must be examined on the subject of the validity period, the truth of its contents and authenticity of the documents.

- The legal consequences of the Sale and Purchase Agreement (SPA) as a preliminary agreement (voor overeenkomst) is binding on the parties who made it, where the parties both sellers and prospective buyers agreed to purchase land and buildings (houses) which will be an agreement between the parties will be poured into the Sale and Purchase Agreements in accordance with what has been agreed. The agreement of the parties indicating their legal effect desired by the parties to implement the substance of the SPA which is preliminary sale and purchase agreement.

\subsection{Suggestion}

Of all the things that have been written by the author based on the research results, the authors can submit suggestions as follows:

- In order for the manufacturing process of Sale and Purchase Agreement (SPA) for the transition of land rights for the purchase of the practice in the running as well as it should, then the parties must meet certain requirements set by the Public. And good communication between the parties involved in the buying and selling process with goodwill and a sense of responsibility.

- We recommend that the Sale and Purchase Agreement (SPA) will be stipulated in the laws and regulations specific to the format of the standard so that the parties put on sale as a preliminary agreement on the sale and purchase of land rights is well protected, and preferably in a manufacturing agreement Purchase (SPA) made by or in the presence of PPAT must explicitly write its articles on the clause concerning the conditions canceled until the injured party because the other party can claim breach of contract cancellation

\section{References}

[1] Abdul Kadir Muhammad, 1980, Hukum Perjanjian, Singapore: Alumni 
eISSN : 2581-2114, pISSN: 2406-9426

[2] Bambang Sunggono, 2003, Metodologi Penelitian Hukum, Jakarta: PT.Raja GRAFINDO PERSADA

[3] C. Djemabut Blaang, 1986, Perumahan dan Pemukiman sebagai Kebutuhan Pokok, Obor Jakarta, Indonesia

[4] Cholid Narbuko and H. Abu Achmadi, 2002, Metodologi Penelitian, Jakarta: PT.Bumi Character

[5] Harun Al Rashid, 1987, Sekilas Tentang Jual Beli Tanah, Ghalia Jakarta, Indonesia

[6] HMT Sahat Sinaga, 2007, Jual Beli Tanah dan Pencatatan Peralihan Hak, Sutra Library, Bandung

[7] Jimmy sembiring Joses, 2010, Panduan Mengurus Sertifikat Tanah, Visimedia, Jakarta

[8] R. Subekti, 1998, Aspek-Aspek Hukum Perikatan Nasional, Citra Aditya Bakti, Bandung

[9] Saleh, 2004, Pengantar Ilmu Hukum, Jakarta: Sinar Grafika 